\title{
The New Path of Ideological and Political Education of Higher Vocational Students from the Perspective of New Media
}

\author{
Wang Jing Wang Liying \\ Author information: Wang Jing,Student Work Department, Tianjin Vocational Institute, Tianjin 300410, China. Email: \\ 16118831@qq.com. \\ Author information: Wang Liying,School of Electromechanical Engineering and Automation,Tianjin Vocational Institute, \\ Tianjin 300410, China.
}

\begin{abstract}
:
With the rapid development of the internet, new media has become an indispensable part of people's daily life. This paper analyses the characteristics of new media in detail, and expounds what difficulties the ideological and political education of higher vocational students is facing in the perspective of new media. At the same time, it also puts forward a new path for the development of ideological and political education of higher vocational students.
\end{abstract}

Keywords: new media, ideological and political education, new path

\section{新媒体视域下高职学生思想政治教育新路径}

\section{王敬 王丽颖}

作者信息：王敬，天津职业大学学工部，中国，天津 300410，邮箱：16118831@qq.com。

作者信息: 王丽颖, 天津职业大学机电工程与自动化学院, 中国, 天津 300410。

\section{摘要:}

随着互联网的快速发展，新媒体已成为人们日常生活中必不可缺的一部分，本文详细地分析了新媒体 的特点, 并阐述了在新媒体视域下高职学生思想政治教育面临了哪些困境。同时, 也提出了高职学生 思想政治教育发展的新路径。

关键词: 新媒体; 思想政治教育; 新路径

\section{1.引言}

中共中央、国务院颁布的《关于加强和改进新形势 下高校思想政治工作的意见》 (中发（2016）31 号)中明 确提出: “加强互联网思想政治工作载体建设。树立互联 网思维, 推动思想政治工作传统优势与信息技术高度融 合, 使互联网成为开展思想政治教育的新平台。”2018 年 全国教育大会上再次强调要鼓励各级各类学校与时俱进 创新教育理念和人才培养模式, 发展“互联网+教育”, 这 就意味着对于传统的思政教育模式, 已经不能快速高效 的提升大学生的思想政治素质了, 高等职业院校思想政 治教育工作者需要紧密结合新时代的特点, 努力探索在 新媒体视域下开展高职学生思想政治教育工作的新方法 和新举措, 同时这也是做好学生思想政治教育工作的一 项至关重要的课题。
2.新媒体的特点

\section{（一）内容的丰富性}

在传播内容上，传统的媒体则存在着一定程度的单 一性, 而新媒体毫不夸张地说, 就像一本百科全书, 为 学生打造了一个广阔性的、便利性的信息库。它不仅涉 及到自然科学、天文地理、历史人文、体育娱乐, 还涵 盖了古今中外的文化成果等内容。所以只要在保证互联 网畅通的前提下, 可以通过触摸屏幕或者点击鼠标, 就 能利用方便、快捷、高速的网络搜索功能找到所想要的 内容, 这对于接受新鲜事物能力较强的大学生来说, 既 满足了汲取足够知识的渴望又给他们日常生活带来了极 大的便利 [1]。

（二）信息的即时性

新媒体的即时性可以使思想政治教育工作者迅速有 效地提升工作效率，其中包括 $\mathrm{QQ}$ 、微信、微博和短视频 
心理特点和新媒体传播规律的思想政治教育工作新模式 [3]。由此可见, 在新媒体视域下, 高职思想政治教育工 作者需要及时更新知识结构和教育观念, 来满足当代大 学生的特点和需求。

（二）对大学生认知能力和心理健康的影响

新媒体在传播时, 信息的开放性和海量性给思想政 治教育工作者在引导與论上大大增加了难度。新媒体中 包含的信息极为丰富, 其中有东方文化与西方文化、传 统文化与现代文化、主流思想与非主流思想等, 但内容 又良莠不齐，这对于网络具有极大依赖且社会阅历较浅、 心智尚未成熟的大学生而言, 极易随着新媒体呈现出的 简便、快捷的倾向思维, 而缺乏独立思考, 在很大程度 上容易导致大学生价值观念、人生态度、行为方式等发 生偏颇。而且, 对于刚入学的新生来说, 新的生活目标 还处在迷茫期, 自律意识也不强, 易受外界影响, 最后 有可能沉迷在网络游戏、快餐小说和追剧里, 而无法自 拔。这些问题的存在, 非常不利于当代大学生形成正确 的世界观、人生观和价值观, 也严重影响着他们的身心 健康, 由于他们长期生活在网络世界里, 缺少与外界交 流，甚至还会产生心理问题。

（三）对师生关系的影响

在日常与学生交流的过程中发现, 有些学生在信息 获取的效率上比教师更高, 他们对网络使用的熟练性更 强, 收集信息的速度更早、更全面。如此一来, 就会让 部分学生认为老师的专业技能也不过如此, 甚至在某些 方面上还不如自己。相对于传统意义上的教育, 新媒体 对教师的主导地位和话语主导权都造成了不小的影响。 而且, 学生也可以通过微信公众号、微博和抖音等学习 到相关知识。学生还可以在新媒体平台上把学到的内容 利用 $\mathrm{QQ}$ 、微信、微博等方式进行转发或者用自己的话语 表述出来, 体现了数字化信息时代, 人人都是自媒体, 更充分说明新媒体时代知识传播的效率越来越高。由此 可见, 新媒体时代的到来, 教师高高在上, 学生自主性 学习较差的局面被彻底打破了。

\section{4.新媒体视域下高职学生思想政治教育发展的新路径}

相比传统媒体, 新媒体时代则是一个完全不同的全 新的传播途径和方式, 这就需要我们高职思想政治教育 工作者重新认知, 要积极探索符合新媒体传播规律的, 并结合大学生实际情况的思想政治教育新路径。特别是, 高职思想政治教育工作者要深入思考如何将新媒体融入 高职学生的思想政治教育, 如何充分利用好新媒体这把 “双刃剑”来开展日常工作。综上所述, 笔者建议可以从以 下三个方面来开展:

（一）加强高职思想政治教育工作者队伍建设

高职思想政治教育工作者应尽快适应新媒体这一全 新环境, 重新定位自己在思想政治教育过程中的角色, 真正实现以学生为本, 将新媒体能够有效地融入日常的 思想政治教育中。实现由现实生活的教导者、信息传播 的把关者、知识传递的灌输者转变为虚拟生活的引导者、 信息传播的引路人和学生成长的指引者。在日常工作中, 


\section{致谢}

基金项目：天津职业大学科学研究基金项目新形势下高 等职业院校新媒体平台及平台资源在学生思政教育中的 应用研究。（课题批准编号：20183102）主持人：王敬。

\section{REFERENCES}

[1] Zhang Zhiyun,The influence of new media on college students'outlook of value,in:Ren Hongjun(Eds.),Journal of QuJing Normal University,Qujing City,2013,pp.19-21.

[2] Liu Hongliang,The path of ideological and political education of higher vocational students from the perspective of new media,in:XuXiangyang(Eds.),Journal of Suzhou Education Institute , Suzhou City,2018,pp.56-59 . DOI:10.13985/j.cnki.34-1227/c.2018. 06.018 .

[3] Li Zhi, A new way of ideological and political education development for college students from the perspective of new media,in:Yang Jianxiao(Eds.),Journal of Agricultural University of Hebei( Agriculture \& Forestry Education),Baoding

City,2017,pp.28-33.DOI:10.13320/j.cnki.jauhe.2017.0007.
新媒体资源等方面的意说相关部门要积极有效地 利用校园文化平台来宣传新媒体的道德意识、自律意识 和法制观念。

\section{（三）构筑校园新媒体教育新平台}

新媒体时代, 学生可以随时随地的进行学习, 不需 要固定的位置, 也不用和老师面对面, 这样大大弥补了 传统思想政治教育的不足。因而高职院校必须抢占校园 新媒体主阵地, 积极创建校园网络传播新平台, 比如大 力推进校园门户网站建设, 充分发挥微博、微信、QQ 等 新媒体技术的优势。在创建过程中, 思想政治教育工作 者一方面要本着“围绕学生, 关照学生, 服务学生”的原则, 将新媒体平台运用于学生的日常思想政治教育中。另一 方面还要积极利用他们来开展学生活动, 营造浓厚的积 极向上的校园文化氛围。通过这些举措, 新媒体, 特别 是校园网络将成为学生了解信息、获取知识和课余生活 的主渠道, 真正实现了从大学生的实际出发, 而且有利 于更好地弘扬共同理想、凝聚精神力量和建设道德风尚。 通过开展学生活动, 大学生也由最初盲目的使用新媒体 到充分地利用新媒体，从而促进全校师生共同建立、共 同维护和共同分享校园新媒体。由此, 校园新媒体不再 是一种可有可无的形式, 而是真正能成为一个立德树人 的新阵地、校园文化传播的新空间和服务师生的新平台。 总之, 在新媒体时代下, 高职学生思想政治教育工 作既面临着大好机遇, 也迎来了严峻挑战。作为高职思 想政治教育工作者, 要及时调整心态, 树立创新意识, 充分利用好这把“双刃剑”, 努力把学生培养成德智体美劳 全面发展的社会主义合格建设者和可靠接班人, 为丰富 和提高思想政治教育工作成效提供新路径。 